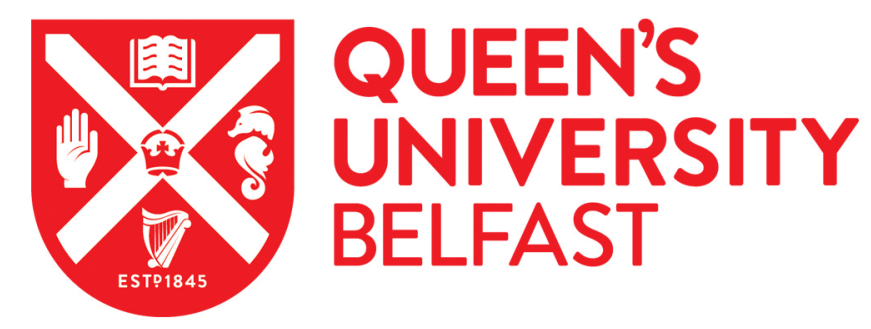

\title{
Explaining voting behaviour on free votes: Solely a matter of preference?
}

Raymond, C., \& Worth, R. M. (2016). Explaining voting behaviour on free votes: Solely a matter of preference? British Politics. https://doi.org/10.1057/s41293-016-0023-7

\author{
Published in: \\ British Politics
}

Document Version:

Peer reviewed version

Queen's University Belfast - Research Portal:

Link to publication record in Queen's University Belfast Research Portal

\section{Publisher rights}

Copyright 2016 Springer

This is a post-peer-review, pre-copyedit version of an article published in British Politics. The definitive publisher-authenticated version is available online at: http://link.springer.com/article/10.1057/s41293-016-0023-7.

\section{General rights}

Copyright for the publications made accessible via the Queen's University Belfast Research Portal is retained by the author(s) and / or other copyright owners and it is a condition of accessing these publications that users recognise and abide by the legal requirements associated with these rights.

Take down policy

The Research Portal is Queen's institutional repository that provides access to Queen's research output. Every effort has been made to ensure that content in the Research Portal does not infringe any person's rights, or applicable UK laws. If you discover content in the Research Portal that you believe breaches copyright or violates any law, please contact openaccess@qub.ac.uk. 


\title{
Explaining voting behaviour on free votes: Solely a matter of preference?
}

\author{
Christopher D. Raymond \\ Lecturer in Politics \\ Queen's University Belfast \\ C.Raymond@qub.ac.uk \\ Robert M. Worth \\ PhD Candidate \\ University of New Orleans \\ rworth@my.uno.edu
}

\section{Key Words}

Free votes; preferences; party identification

\begin{abstract}
While studies examining free votes find MPs' preferences influence their voting behaviour, most studies also show MPs tend to divide along party lines even after the whips have been withdrawn. Recent work offers a possible alternative explanation for this finding: this sustained party cohesion represents the impact of MPs' party identification similar to party identification effects in the electorate. This argument is tested using a series of free votes on same-sex relations. Even after controlling for preferences using several direct measures, party continues to shape voting behaviour. Although indirect, this provides evidence in favour of the party-asidentification argument.
\end{abstract}

\section{Notes}

We would like to thank Pippa Norris for generously sharing the British Representation Study data with us. All responsibility for their use, and especially any errors, belongs to us. 
British parties are known for their strict discipline. Though backbench dissent has been on the rise in recent years (Cowley and Stuart, 2012), historically, Members of Parliament (MPs) in the House of Commons have followed the party line—or been compelled by their party's whips to maintain the party line—on most divisions. Even after the whips have been withdrawn, a sizable body of research examining 'free votes' (un-whipped divisions) finds that parties often remain highly cohesive. Most of these studies maintain that the sustained effect of 'party' on these divisions reflects the shared preferences of party members (e.g. Cowley and Stuart, 2010; Hibbing and Marsh, 1987; Marsh and Read, 1988; Mughan and Scully, 1997; Plumb, 2013, 2015).

Recently, however, an alternative explanation of 'party' effects has emerged maintaining that MPs' party identifications also influence their voting behaviour. Similar to party identification in the electorate (Campbell et al., 1960; Green, Palmquist, and Schickler, 2002), this argument holds that MPs feel psychological attachments to their parties and are socialised in ways that compel them to act in the best interests of the party, even if their personal preferences do not line up with the party's interests (Norton, 2003; Raymond and Overby, 2014; Russell, 2014; see also Plumb and Marsh, 2013). The implications of this argument are clear: net of personal preferences, MPs of the same party will vote en bloc. However, this argument has yet to be subjected to proper empirical scrutiny, as the one direct test of the party-as-identification argument (Raymond and Overby, 2014) examined only one division, which questions the generalisability of that study's findings. Thus, further empirical scrutiny is needed before one can conclude that MPs’ party identifications indeed shape their voting behaviour.

Towards this end, this paper examines the impact of party identification on a series of free votes dealing with same-sex relations. Free votes are interesting divisions in which to 
examine the voting behaviour of MPs because they are votes held on what are often divisive moral issues that genuinely allow MPs to vote according to the dictates of their consciences without fear of repercussions from party leaders (Richards, 1970). As a result, this allows us to rule out effects related to party whips' efforts to maintain discipline.

As previous research shows that 'party' continues to impact voting behaviour on free votes, most have taken this as evidence that cohesion occurs due to the shared preferences of MPs of the same party. However, if 'party' continued to influence MPs' voting behaviour even after accounting for MPs’ preferences, this would demonstrate that shared preferences alone cannot explain the sustained party cohesion observed on such free votes. Although we lack specific measures of party identification, this would provide support for the notion that MPs party identifications impact voting behaviour.

In most cases, reaching such conclusions—regarding the effects of both party identification and personal preferences—is hampered by the fact that researchers lack direct measures of MPs' preferences. Some research attempts to measure MPs’ preferences using previous voting behaviour (e.g. Plumb, 2015; Plumb and Marsh, 2011); however, such measures are problematic for two main reasons. For one, voting might not reflect MPs' true preferences (e.g. such votes may be tactical, reflecting pressures from constituents instead of their own preferences). Second, the bills that are voted on are not randomly selected, as party leaders are loathe to allow bills to the floor that divide their caucuses (e.g. Carrubba, Gabel, and Hug, 2008; Cox and McCubbins, 2005). As a result, direct measures of MPs' preferences are preferable.

To measure MPs' preferences, this paper makes use of a rare data set surveying MPs in the House of Commons. Namely, we use the British Representation Study 1997 (Norris and Lovenduski, 1997), which includes a range of questions measuring preferences relevant to voting 
on the issue of same-sex relations. Should we find that party continues to influence voting behaviour even after controlling for MPs’ preferences, the fact we have precise measures of MPs' preferences specific to the issue at hand would increase our confidence in concluding that this residual party effect is not merely capturing some unmeasured preference-thereby providing indirect evidence of a party-as-identification effect.

The next section discusses the details of our analysis and interprets the results. Specifically, we examine whether support for several bills that sought to standardise age-ofconsent laws for same-sex relationships was determined solely by MPs’ personal preferences, or whether there is evidence to suggest MPs’ party identifications also affected their voting behaviour. We first discuss the details of the four free vote divisions examined in the empirical analysis before outlining the research design and discussing the results of our regression models predicting support for each division. A concluding section discusses the implications of our findings for the larger body of research examining voting behaviour on free votes, as well as future avenues for research regarding the party identification of MPs.

\section{Analysis of Four Free Vote Divisions}

We examine MPs’ voting behaviour on four divisions relating to efforts to standardise laws regarding age of consent for consensual sexual acts—specifically, to reduce the age of consent for certain homosexual acts (namely, anal sex) to 16. Proponents of these efforts argued that reducing the age of consent to 16 was necessary to eliminate sexual orientation-based discrimination against males. An initial attempt to reduce the age of consent was made with a proposed amendment to the Crime and Disorder Act 1998 (see the debate in Hansard on 22 June 1998, column 709). This amendment was passed on second reading, but was later rejected by

the House of Lords. Rather than confront the House of Lords, the Blair government dropped this 
amendment from the Crime and Disorder Act and introduced a new, separate bill, which eventually became the Sexual Offences (Amendment) Act 2000. This bill initially passed on second reading on 25 January 1999 (see Hansard on that date at column 20), but was again rejected by the House of Lords. Invoking the Parliament Acts 1911 and 1949 in order to override the Lords' suspensive veto, the House of Commons passed the bill again on second reading on 10 February 2000 (Hansard, column 432). The bill then passed on third reading on 28 February 2000 (Hansard, column 127), receiving royal assent on 30 February 2000.

As one can see in Table 1, which presents the percentages of the three major parties' MPs voting in favour of standardising age-of-consent laws, each division broke down along party lines. (Because only a handful of MPs from Northern Ireland and the nationalist parties in Scotland and Wales voted on each measure, we omit these MPs from Table 1.) For the sake of reference, the percentages of each party's MPs voting to standardise age-of-consent laws obtained from the sample of MPs included in the British Representation Study are presented in parentheses. On each division, Labour MPs were nearly unanimous in their support for standardising age-of-consent laws, with no fewer than 94 per cent of Labour MPs voting in favour. Only slightly less cohesive in their support, Liberal Democrat MPs voted overwhelmingly in favour of standardising age-of-consent laws, with between 84 and 93 per cent of Liberal Democrat MPs supporting each measure. To a nearly equal degree, the overwhelming majority of Conservative MPs voted against standardising age-of-consent laws, with Conservative support on each division ranging from roughly 6 to 15 per cent. With the exception of Conservative MPs (more on this point below), these percentages are reflected closely in the sample of MPs interviewed by the British Representation Study. Thus, while MPs were free to vote their consciences, most still chose to vote along party lines. 
While MPs clearly divided along party lines on all four divisions, what remains to be seen is whether this sustained cohesion can be explained solely by the shared preferences among MPs of the same party, or whether there is evidence to suggest that MPs' party identifications also shaped their voting behaviour. To test the party-as-identification argument, we examine support for each of these four divisions, coding those MPs voting in favour of standardising ageof-consent laws as one and zero for those voting against. We include several variables to control for MPs’ preferences. The British Representation Study included four variables measuring attitudes towards issues directly relevant to both the Crime and Disorder Act 1998 amendment and the Sexual Offences (Amendment) Act 2000. On three questions, MPs were asked whether homosexual relations are always wrong, ${ }^{1}$ whether young people lack respect for traditional values, and whether censorship is necessary to uphold moral standards; responses for each question ranged from zero (disagree strongly) to four (agree strongly). A fourth question asked whether people should be tolerant of unconventional lives, with responses ranging from zero (agree strongly) to four (disagree strongly). These variables are turned into an additive social conservatism scale (Cronbach’s alpha $=0.66$ ), ranging from zero (more socially liberal attitudes) to 16 (more socially conservative attitudes). This variable allows us to control for the ideological liberalism/conservatism of MPs, which previous research has shown to play a strong role in determining voting behaviour on free votes (Plumb, 2013; 2014; Plumb and Marsh, 2011; Read, Marsh, and Richards, 1994).

We include three additional variables to control for MPs’ preferences. Because the social conservatism scale may not fully capture all aspects of the underlying ideology affecting MPs' voting behaviour on free votes noted by previous research, we also include MPs' left-right selfplacements using a scale ranging from zero to nine (left to right). To control for the possibility 
that higher education breeds the sort of tolerance on moral issues that might lead MPs to support this bill, we include a variable coded one for those MPs possessing a university degree and zero otherwise. Recognising that gender has played an increasing role in shaping the behaviour of MPs on free votes (Cowley and Stuart, 2010; Plumb, 2013; 2014), we also include a variable coded one for female MPs and zero otherwise.

Additionally, we control for constituency pressures that may either pull MPs away from the rest of their parties and towards their constituents' preferences or push them towards the rest of their fellow MPs (Norton and Wood, 1993; Overby, Raymond, and Taydas, 2011; Pattie, Fieldhouse, and Johnston, 1994). Specifically, we include a variable measuring the percentage of Christians in MPs' constituencies using data from the 2001 Census. $^{2}$ MPs representing constituencies with more Christians may feel pressure to vote against each measure whilst MPs from more secular constituencies may feel pressure to support the reduction in age of consent.

Finally, we include a variable coded one for Conservative MPs and zero otherwise. Though we lack direct measures of party identification, if party remains significant after accounting for the effects of MPs' preferences and constituency pressures, this would provide evidence MPs' party identifications shaped their voting behaviour. We focus on Conservative MPs because opposition to the reduction in the age of consent on each division came primarily from the Conservative ranks. Because the attempt to standardise of age-of-consent laws was supported by the Blair government, some Conservative MPs—including those MPs indifferent to or even supportive of same-sex relationship equality—may have been motivated to vote against the measure principally because it was supported by the Labour leadership (even though the government was not so committed to the bill as to enforce discipline among its cabinet or backbenches). It is important to note that because the British Representation Study sample over- 
represents the percentage of Conservatives deviating from the rest of the party (i.e. it underrepresents Conservative unity), this will bias the results by under-estimating the impact of Conservative party identification on voting behaviour in the analysis conducted here. Thus, the results presented below can be viewed as conservative estimates of the impact of party identification

To estimate support for each division, we use logistic regression. Parameter estimates for all four models are presented in Table 2. Each model has satisfactory fit, correctly predicting more than 90 per cent of the votes in our sample.

The results show the most consistently significant preference variable is the social conservatism scale, which is negatively signed in each model. This indicates that the likelihood of voting in favour of each measure declines as one's degree of social conservatism increases. ${ }^{3}$ While those MPs placing themselves to the right are significantly less likely to vote in favour of the amendment to the Crime and Disorder Act, left-right ideology does not impact voting behaviour on any of the Sexual Offences (Amendment) Act divisions. Those with university educations are significantly more likely to vote for the Sexual Offences (Amendment) Act on third reading, but are not significantly different on the other three divisions. Female MPs are significantly more likely to vote in favour of the Sexual Offences (Amendment) Act on second reading in 1999, but not significantly different in their voting behaviour on other divisions.

Even after controlling for preferences, however, party remains a statistically significant predictor in each model. The negative coefficient indicates that Conservative MPs are significantly less likely to vote in favour of standardising age-of-consent laws on each division. Thus, while 'party' defined as shared preferences plays a big role, preferences alone cannot explain this sustained party effect. This, in turn, suggests MPs' party identification may have 
shaped their voting behaviour on these four divisions.

To put the impact of each variable in some perspective, Table 3 presents the predicted changes in probabilities for each variable when moving from their lowest to their highest values (holding all other variables at their medians) using the results from each model. In all four models, party plays a major role, substantially decreasing the predicted probabilities of voting for each bill. Support for the second and third readings of the Sexual Offences (Amendment) Act in 2000 is 38 and 39 percentage points, respectively, lower among Conservative than all other MPs. While the predicted decrease in the probability of voting for the proposed amendment to the Crime and Disorder Bill 1998 associated with party is somewhat smaller (decreasing by 27 per cent), Conservative MPs are 72 percentage points less likely to vote in favour of the second reading of the Sexual Offences (Amendment) Act in 1999. These effects are sizable in relation to the impact of preferences and constituency pressures, exceeding the effects of nearly every preference measure. While the estimated effects of social conservatism are greater than the estimated effects of party, the changes in probabilities due to party rival the changes in probabilities due to social conservatism in all but the model predicting support for the Sexual Offences (Amendment) Act on second reading in 2000 (and even then the effect of party is nearly half the size of the change in probability due to social conservatism). Thus, the estimated effects of party are quite strong.

\section{Discussion}

Though the whips are withdrawn on free votes, 'party' continues to exert an effect on MPs’ voting behaviour. While most previous studies argue that this sustained party cohesion occurs because MPs of the same party possess similar preferences, an alternative argument holds that party cohesion is also maintained by MPs' party identification. Given the paucity of tests of 
this argument, this paper has examined the voting behaviour of MPs on four divisions in order to determine the robustness of this party-as-identification argument. Using specific measures of preferences, the results show that, consistent with previous literature, MPs' preferences exert strong effects on the voting behaviour of MPs. However, the results also suggest the lingering effect of 'party' on free votes seen in previous research may not be due solely to shared preferences among MPs of the same party: even after controlling for MPs' preferences, 'party' still has an impact on MPs' voting behaviour on these four divisions. Though this only constitutes an indirect test of the party identification argument, the results suggest party identification may also explain MPs' voting behaviour. If correct, the findings presented above suggest the continued effect of party seen in previous studies of voting behaviour on free votes may have reflected more than simply the shared preferences of MPs belonging to the same party.

While these findings suggest the party-as-identification argument deserves serious consideration, further research is still needed to corroborate these findings. Particularly, future research employing more direct measures of party identification is needed in order to demonstrate that the party identification of MPs—and not some hitherto unexplored factor related to the party affiliation of MPs—indeed shapes their voting behaviour. Though the lack of such alternative explanations for the residual party effect seen above provides support for the party-as-identification argument, future research must provide more direct evidence of party identification effects.

Additionally, even though this study corroborates the findings in Raymond and Overby (2014), it is difficult to say conclusively that party identification effects are present on every free vote—let alone all divisions (or in all legislatures)—on the basis of a handful of free votes dealing with specific issues. Because of this, future research examining the impact of party 
identification will have to grapple not only with different issues but also different types of divisions, especially whipped divisions, if this party identification argument can be viewed as truly generalizable. This is particularly important considering that party leaders strategically avoid issues with the potential to divide their party's members and threaten the party's agenda (e.g. Carrubba, Gabel, and Hug, 2008; Cox and McCubbins, 2005). As a result, free votes are often allowed only when parties are internally divided between groups of MPs with very strong and/or divergent preferences. Because the issues normally decided as free votes are non-random, future research examining whether the party identification of MPs impacts voting behaviour more generally will need to examine whipped divisions as well.

That being said, it is not too premature to acknowledge that the findings presented here compel researchers to take the possibility of party identification effects on MPs' voting behaviour more seriously in future research. If additional scholarship addressing the shortcomings in the research design of this study continues to find evidence supporting the partyas-identification argument, then this would require re-evaluation of the role that 'party' plays in shaping the voting behaviour of MPs. 
Table 1: The Representativeness of the British Representation Study Sample Relative to the Outcome of Each Division (by Party)

\begin{tabular}{|c|c|c|c|c|}
\hline \multirow[b]{3}{*}{ Party } & \multicolumn{4}{|c|}{ Division } \\
\hline & \multirow{2}{*}{$\begin{array}{l}\text { Crime and Disorder Act } \\
\text { Amendment } \\
\text { (1998) }\end{array}$} & \multicolumn{3}{|c|}{ Sexual Offences (Amendment) Act } \\
\hline & & $\begin{array}{l}2^{\text {nd }} \text { Reading } \\
\text { (1999) }\end{array}$ & $\begin{array}{l}2^{\text {nd }} \text { Reading } \\
(2000)\end{array}$ & $\begin{array}{l}3^{\text {rd }} \text { Reading } \\
(2000)\end{array}$ \\
\hline Labour & $95.6(94.9)$ & $94.8(94.1)$ & $97.5(96.3)$ & $98.2(96.7)$ \\
\hline Conservative & $14.7(16.3)$ & $6.3(11.1)$ & $11.0(21.6)$ & $11.6(18.6)$ \\
\hline Liberal Democrat & $91.2(91.7)$ & $90.3(90.0)$ & $84.2(84.6)$ & $92.9(89.5)$ \\
\hline
\end{tabular}

Entries are the percentages of each party's MPs voting 'aye' on each division (with the sample percentages observed in the British Representation Study sample in parentheses). 
Table 2: Determinants of Support for Four Divisions Regarding Age-of-Consent

\begin{tabular}{|c|c|c|c|c|}
\hline \multirow[b]{2}{*}{ Predictors } & \multicolumn{4}{|c|}{ Division } \\
\hline & $\begin{array}{l}\text { Amendment } \\
\text { (1998) }\end{array}$ & $\begin{array}{l}2^{\text {nd }} \text { Reading } \\
\text { (1999) }\end{array}$ & $\begin{array}{l}2^{\text {nd }} \text { Reading } \\
(2000)\end{array}$ & $\begin{array}{l}3^{\text {rd }} \text { Reading } \\
(2000)\end{array}$ \\
\hline Social Conservatism & $\begin{array}{l}-0.52^{*} \\
(0.18)\end{array}$ & $\begin{array}{l}-0.45^{*} \\
(0.16)\end{array}$ & $\begin{array}{l}-0.63^{*} \\
(0.22)\end{array}$ & $\begin{array}{l}-0.49^{*} \\
(0.19)\end{array}$ \\
\hline Church Attendance & $\begin{array}{l}-0.47 \\
(0.35)\end{array}$ & $\begin{array}{l}-0.39 \\
(0.30)\end{array}$ & $\begin{array}{l}-0.40 \\
(0.36)\end{array}$ & $\begin{array}{l}-0.18 \\
(0.39)\end{array}$ \\
\hline Left-Right Position & $\begin{array}{l}-0.44^{*} \\
(0.22)\end{array}$ & $\begin{array}{l}-0.06 \\
(0.24)\end{array}$ & $\begin{array}{l}-0.16 \\
(0.22)\end{array}$ & $\begin{array}{l}-0.29 \\
(0.28)\end{array}$ \\
\hline University Education & $\begin{array}{l}0.62 \\
(0.88)\end{array}$ & $\begin{array}{l}0.45 \\
(0.78)\end{array}$ & $\begin{array}{l}1.29 \\
(0.95)\end{array}$ & $\begin{array}{l}2.32^{*} \\
(1.19)\end{array}$ \\
\hline Female & $\begin{array}{l}0.68 \\
(1.33)\end{array}$ & $\begin{array}{l}2.32 * \\
(1.27)\end{array}$ & $\begin{array}{l}0.53 \\
(1.30)\end{array}$ & $\begin{array}{l}1.18 \\
(1.47)\end{array}$ \\
\hline \% Christian & $\begin{array}{l}<-0.01 \\
(0.05)\end{array}$ & $\begin{array}{l}<-0.01 \\
(0.05)\end{array}$ & $\begin{array}{l}0.03 \\
(0.05)\end{array}$ & $\begin{array}{l}0.04 \\
(0.06)\end{array}$ \\
\hline Conservative MPs & $\begin{array}{l}-2.44^{*} \\
(1.04)\end{array}$ & $\begin{array}{l}-4.17 * \\
(1.29)\end{array}$ & $\begin{array}{l}-3.24^{*} \\
(1.23)\end{array}$ & $\begin{array}{l}-3.89 * \\
(1.44)\end{array}$ \\
\hline Constant & $\begin{array}{l}8.33^{*} \\
(4.46)\end{array}$ & $\begin{array}{l}5.83 \\
(3.60)\end{array}$ & $\begin{array}{l}5.39 \\
(3.60)\end{array}$ & $\begin{array}{l}3.47 \\
(4.02)\end{array}$ \\
\hline $\operatorname{LR} X^{2}$ & $112.57^{*}$ & 104.66* & $94.36^{*}$ & $112.57^{*}$ \\
\hline \% Correctly Classified & $91 \%$ & $93 \%$ & $91 \%$ & $93 \%$ \\
\hline McFadden's $\mathrm{R}^{2}$ & 0.66 & 0.64 & 0.63 & 0.68 \\
\hline $\mathrm{n}$ & 148 & 143 & 133 & 149 \\
\hline
\end{tabular}

${ }^{*} \mathrm{p}<0.05$, one-tailed tests. Standard errors in parentheses. 
Table 3: Predicted Effects of Each Variable on the Probability of Voting ‘Aye’ on Each Division

\begin{tabular}{lllll}
\hline & \multicolumn{4}{c}{ Division } \\
\cline { 2 - 5 } Predictors (range) & $\begin{array}{l}\text { Amendment } \\
2^{\text {nd }} \text { Reading } \\
2^{\text {nd }} \text { Reading }\end{array}$ & $\begin{array}{l}3^{\text {rd }} \text { Reading } \\
(2090)\end{array}$ \\
\hline Social Conservatism (0-16) & -0.71 & -0.74 & -0.81 & -0.40 \\
Church Attendance (0-4) & -0.08 & -0.08 & -0.04 & -0.01 \\
Left-Right Position (0-9) & -0.34 & -0.03 & -0.05 & -0.07 \\
University Education (0-1) & 0.03 & 0.03 & 0.06 & 0.11 \\
Female (0-1) & 0.02 & 0.04 & 0.01 & 0.01 \\
\% Christian (40.7-87.3) & -0.01 & $<-0.01$ & 0.04 & 0.03 \\
Conservative MPs (0-1) & $\mathbf{- 0 . 2 7}$ & $\mathbf{- 0 . 7 2}$ & $\mathbf{- 0 . 3 8}$ & $\mathbf{- 0 . 3 9}$ \\
\hline
\end{tabular}

Entries are the predicted changes in probabilities when moving from the minimum to the maximum value (holding all other variables at their median values). 


\section{References}

Campbell, A., Converse, P. E., Miller, W. E. and Stokes, D. E. (1960) The American Voter. New York: John Wiley and Sons.

Carrubba, C., Gabel, M. and Hug, S. (2008) Legislative Voting Behavior, Seen and Unseen: A Theory of Roll-Call Vote Selection. Legislative Studies Quarterly 33(4): 543-572.

Cowley, P. and Stuart, M. (2010) Party Rules, OK: Voting in the House of Commons on the Human Fertilisation and Embryology Bill. Parliamentary Affairs 63(1): 173-181.

Cowley, P., \& Stuart, M. (2012) A coalition with two Wobbly Wings: Backbench dissent in the house of commons. Political Insight 3(1): 8-11.

Cox, G. W. and McCubbins, M. D. (2005) Setting the agenda: Responsible party government in the US House of Representatives. New York: Cambridge University Press.

Green, D. P., Palmquist, B. and Schickler, E. (2002) Partisan Hearts and Minds: Political Parties and the Social Identities of Voters. New Haven: Yale University Press.

Hibbing, J. R. and Marsh, D. (1987) Accounting for the Voting Patterns of British MPs on Free Votes. Legislative Studies Quarterly 12(2): 275-297.

Marsh, D. and Read, M. (1988) Private Members' Bills. New York: Cambridge University Press.

Mughan, A. and Scully, R. M. (1997) Accounting for Change in Free Vote Outcomes in the House of Commons. British Journal of Political Science 27(4): 640-647.

Norris, Pippa and Lovenduski, Joni. (1997). British Representation Study, 1997. Available online at: 35 http://ksghome.harvard.edu/ pnorris/Data/data.htm.

Norton, P. and Wood, D. M. (1993) Back from Westminster. Lexington: University Press of Kentucky.

Overby, L. M., Raymond, C. and Taydas, Z. (2011) Free votes, MPs, and constituents: The case of same-sex marriage in Canada. American Review of Canadian Studies 41(4): 465-478.

Pattie, C., Fieldhouse, E. and Johnston, R. J. (1994) The Price of Consciences: The Electoral Correlates and Consequences of Free Votes and Rebellions in the British House of Commons, 1987-1992. British Journal of Political Science 24(3): 359-380.

Plumb, A. (2013) Research Note: A Comparison of Free Vote Patterns in Westminster-Style Parliaments. Commonwealth \& Comparative Politics 51(2): 254-266.

Plumb, A. (2015) How Do MPs in Westminster Democracies Vote When Unconstrained by Party Discipline? A Comparison of Free Vote Patterns on Marriage Equality Legislation. Parliamentary Affairs 68(3): 533-554.

Plumb, A. and Marsh, D. (2011) Divisions in the Conservative Party on Conscience Issues: 
Comment on Philip Cowley and Mark Stuart, 'Party Rules, OK: Voting in the House of Commons on the Human Fertilisation and Embryology Bill’. Parliamentary Affairs 64(4): 769776.

Plumb, A. and Marsh, D. (2013) Beyond party discipline: UK Parliamentary voting on fox hunting. British Politics 8(3): 313-332.

Raymond, C.D. and Overby, L. M. (2014) What's in a (Party) name? Examining preferences, discipline, and social identity in a parliamentary free vote. Party Politics, DOI: $10.1177 / 1354068814549346$.

Read, M., Marsh, D. and Richards, D. (1994) Why Did They Do It? Voting on Homosexuality and Capital Punishment in the House of Commons. Parliamentary Affairs 47(3): 374-386.

Richards, P. G. (1970) Parliament and Conscience. London: George Allen and Unwin.

Russell, M. (2014) Parliamentary Party Cohesion: Some Explanations from Psychology. Party Politics 20(5): 712-723. 
${ }^{1}$ Because the variable capturing attitudes towards homosexual relationships most closely measures the issue at hand, we also ran models substituting the social conservatism scale with this one variable alone. The results produced by these alternative models were substantively identical to those presented here.

${ }^{2}$ Data for this variable are only available for England and Wales. Recognising this excludes Scottish MPs, we re-estimated each model using multiple imputation, which produced findings substantively equivalent to those presented here.

${ }^{3}$ We also explored the possibility that MPs with more socially conservative values have more intense preferences against each bill than more socially liberal MPs by estimating alternative model specifications including a quadratic term for the social conservatism variable. The results of these robustness tests were substantively equivalent to those presented here. 